\author{
Марко Милосављевић ${ }^{1}$, Драгана Даковић ${ }^{2}$, Адријана Милосављевић $^{2}$, \\ Јована Јовановић ${ }^{3}$, Немања Ранчић ${ }^{4}$ \\ ${ }^{1}$ Факултет медицинских наука, Универзитет у Крагујевцу \\ ${ }^{2}$ Војномедицинска академија, Београд \\ ${ }^{3}$ Стоматолошки фракултет, Универзитет у Београду \\ ${ }^{4}$ Центар за клиничку фармакологију, Медицински фракултет \\ Војномедицинске академије, Универзитет одбране у Београду
}

\title{
ORAL HEALTH OF 20 TO 64 YEARS OLD MILITARY INSUREES MEASURED BY DMFT INDEX: A PILOT STUDY
}

\author{
Marko Milosavljevićc , Dragana Dakovićc ${ }^{2}$, Adrijana Milosavljević \\ Jovana Jovanović ${ }^{3}$, Nemanja Rančić ${ }^{4}$ \\ ${ }^{1}$ The Faculty Medical Sciences, University of Kragujevac \\ ${ }^{2}$ Military Medical Academy, Belgrade \\ ${ }^{3}$ School of Dentistry, University of Belgrade \\ ${ }^{4}$ Centre for Clinical Pharmacology, Medical Faculty Military Medical Academy, \\ University of Defense, Belgrade
}

\section{СКРАЋЕНИЦЕ:}

КЕП индекс - индекс каријесних, екстрахованих и пломбираних зуба

СЗО - Светска здравствена организација

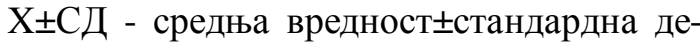
вијација

$\chi^{2}$ - хи-квадрат тест

$\mathrm{U}$ - Ман-Витнијев У тест

$\mathrm{C}^{2}$ - Крушкал-Волисов тест

F - AHOBA

$\mathrm{r}$ - Спирманова корелација ранга

p - ниво статистичке значајности

К - број каријесних зуба

Е - број екстрахованих зуба

П - број пломбираних зуба

\section{САЖЕТАК}

Циљ: Циљ овог истраживања био је да се утврди статус оралног здравља, као и заступљеност општих и локалних фактора који могу утицати на ниво оралног здравља.

Пацијенти и методи: Урађена је проспективна пилот студија пресека (опсервационог типа) 52 испитаника (32 мушкараца и 20 жена) просечне старости $40,4 \pm 12,7$ година. Анализиране су све категорије војних осигураника од 20-64 година старости, подељене у три старосне групе: 20-34, 35-44 и 45-64 година. Студија је урађена на Одељењу за здравствену заштиту војних осигураника у Панчеву.

Резултати: Од укупног броја испитаника, 25 или 48,1\% је старости 20-34 година. Већина користи просте шећере у исхрани $(90,4 \%)$ и газирана пића $(63,5 \%)$ барем једном

Контакт: Марко Милосављевић Факултет медицинских наука, ул. Светозара Марковића 69, 34000 Крагујевац, Србија e-mail: drm.milosavljevic@yahoo.com 
у току недеље. Од укупног броја испитаника већина не користи течности за испирање уста (76,9\%), интерденталне четкице $(86,5 \%)$ и конац за зубе $(73,1 \%)$. Код испитаника који не користе конац за зубе статистички је знатно већи индекс каријесних, екстрахованих и пломбираних зуба (КЕП индекс) (U=130; $\mathrm{p}=0,05)$. Око половина испитаника има крварење десни у току прања зуба (24; 46,2\%). Највећи број испитаника има лошу технику прања зуба $(82,7 \%)$. Просечан КЕП индекс код свих испитаника јесте $15,69 \pm 4,80$, и не постоји статистички значајна разлика између старосних категорија $(\mathrm{F}=1,945 ; \mathrm{p}=0,154)$. Међутим, постоји статистички значајна разлика између старосних категорија у екстрахованим зубима $(F=9,700 ; p=0,000)$. Највећа просечна вредност екстрахованих зуба је у групи од 35 44 година $(6,56 \pm 3,88)$.

Закључак: Иако постоји високо развијена свест о утицају оралног здравља на опште здравствено стање код свих испитаника, већина испитаника има висок КЕП индекс.

Кључне речи: КЕП индекс, војна популација, орално здравље

\section{ABSTRACT}

Objective: The aim of this study was to determine the oral health status, as well as influence of general and local factors that may affect the level of oral health.

Patients and methods: We have done a prospective cross-sectional pilot study (observational type) with 52 examinees ( 32 men and 20 women), mean age $40.4 \pm 12.7$ years. We analyzed all categories of military insurees between 20 and 64 years of age. They were divided into three age groups: $20-34,35-44$ and $45-64$ years. The study was conducted in the Department of Military Health Care, Pancevo, Serbia.

Results: There were 25 examinees (48.1\%) between 20 and 34 years of age. Majority of the examinees used simple sugars $(90.4 \%)$ and fizzy drinks $(63.5 \%)$ in their diet at least once a week. Majority of the examinees did not use mouthwashes (76.9\%), interproximal brushes $(86.5 \%)$ or dental floss $(73.1 \%)$. Examinees who did not use dental floss, had significantly higher decayed, missing and filled teeth index (DMFT index $)(U=130 ; p=0.05)$. About half of the examinees experienced bleeding from gums during tooth brushing $(24 ; 46.2 \%)$. Majority of the examinees had bad teeth brushing technique $(82.7 \%)$. The average value of DMFT index in all examinees was $15.69 \pm 4.80$, and there was no significant difference between the age groups $(\mathrm{F}=1.945 ; \mathrm{p}=0.154)$. However, there were significant differences between the age groups in missing teeth $(\mathrm{F}=9.700 ; \mathrm{p}=0.000)$. The highest average value of missing teeth was in the group of $35-44$ years olds $(6.56 \pm 3.88)$.

Conclusions: Although there was high level of awareness among the examinees about the influence of oral health to general health, majority of them had high value of the DMFT index.

Key Words: DMF index, Military Personnel, Oral health

\section{УВОД}

Орално здравље представља стање здравља свих анатомских и функционалних делова усне дупље и један је од битних показатеља квалитета здравља популације ${ }^{1}$. У очувању оралног здравља навике појединаца, али и њихов социо-економски статус, ниво образовања, верска и културна обележја, могу имати битан утицај ${ }^{2,3}$.

Према литературним наводима, најраспрострањеније обољење усне дупље и најчешћи разлог губитка зуба јесте зубни каријес ${ }^{4}$.

Примарни етиолошки фактор у настанку обољења зуба је зубни плак. У студијама бројних аутора доказана је директна веза између распрострањености зубног плака и обољења зуба ${ }^{6,7}$. Зубни плак представља сложену бактеријску заједницу чији опстанак зависи од пријемчивости ткива, као и могућности преживљавања и раста бактерија у датом окружењу ${ }^{8}$. Као последица неадекватне хигијене усне дупље бактерије плака користе ферментабилне угљене хидрате са површине зуба, што за последицу има стварање киселе средине, која утиче на деминерализацију зуба и настанак каријеса зуба. Стога, Axelsson и cap. ${ }^{9}$ и Lang и cap. ${ }^{10}$, наводе да механичка елиминација плака средствима за одржавање оралне хигјене (четкица за зубе, конац за зубе, интерденталне четкице), јесте најбољи начин у превенцији обољења усне дупље.

С друге стране, и правилна исхрана може да представља веома важан фактор у очувању оралног здравља, јер значајно утиче на квалитет и састав пљувачке, као и на киселост зубног плака ${ }^{11,12}$.

Циљ овог истраживања био је да се утврди статус оралног здравља, као и заступљеност општих и локалних фактора који могу 
утицати на ниво оралног здравља, у популацији војних осигураника старосне доби од 20 до 64 године, на територији коју покрива Bojна амбуланта у Панчеву.

\section{ПАЦИЈЕНТИ И МЕТОД}

Испитивање је обављено као студија пресека и спроведено је у Војној амбуланти у Панчеву у трајању од 30 дана (април 2012. године), од стране једног стоматолога. Овим истраживањем обухваћена су 52 испитаника, сви војни осигураници, оба пола, старости од 20 до 64 године. Испитаници су подељени у три старосне категорије: 20-34, 35-44 и 45-64 година. У истраживање су били укључивани сви испитаници који су се јавили у стоматолошку амбуланту ради неке од стоматолошких интервенција (тзв. згодни узорак). Сваки испитаник је после пружених информација о самој студији од стране ординирајућег лекара потписао добровољни пристанак за учешће у студији.

Студија се састојала од анкете "затвореног типа", коју је попуњавао испитаник, и клиничког прегледа зуба од стране ординирајућег стоматолога.

Анкета се састојала од 22 питања везаних за:

- опште животне навике испитаника (начин исхране, конзумирање газираних пића, простих шећера и алкохола, пушење),

- навике испитаника у одржавању оралне хигијене, као локалне факторе који могу утицати на настанак каријеса зуба (учесталост прања зуба и мењања четкице за зубе, временско трајање прања зуба, коришћење конца за зубе, интерденталних четкица и течности за испирање уста), као и

- мишљење испитаника о утицају болести уста и зуба на опште здравствено стање.

Стоматолошки преглед подразумевао је:

- оцену технике прања зуба испитаника и,

- клинички преглед зуба испитаника стоматолошком сондом и огледалцем

Процена технике прања зуба, након демонстрације испитаника, оцењивана је од стране ординирајућег стоматолога као: правилна или неправилна.

Након клиничког прегледа зуба испитаника, одређиван је индекс каријесних, екстрахованих и пломбираних зуба (КЕП индекс) сходно препорукама СЗО, за утврђивање преваленције и инциденце каријеса ${ }^{13,14}$.

КЕП индекс представља збир укупног броја каријесних, пломбираних и извађених зуба. Трећи молари, у случају да су изникли, нису урачунати у КЕП индекс. Пломбом се сматрало постојање функционалог интегритета између рубова испуна и зуба, без постојања зјапа. Заливачи фисура су такође нотирани као пломбе. Каријесом је сматрано постојање свих облика каријеса зуба (почетног, дубоког, секундарног-поред пломбе) и деструкција целокупне крунице уз присутво корена тог зуба. Као екстракција је нотиран сваки недостатак зуба у вилици.

Статистичка обрада податка урађена је у рачунарском програму PASW Statistics 18. Све континуалне варијабле су представљене у облику средње вредности \pm стандардна девијација $(X \pm C Д)$, док су категоријске варијабле представљене процентуалном учесталошћу појединих категорија. За категоријске варијабле статистичка значајност разлике испитивана је хи-квадрат тестом $\left(\chi^{2}\right)$, док је за континуалне варијабле коришћен Ман-Витнијев У тест (U) и Краскал-Волисов тест $\left(\mathrm{C}^{2}\right)$, пошто се радило о подацима који не задовољавају критеријуме за нормалну расподелу према Колмогоров-Смирновљевом тесту. За испитивање значајности разлике континуалних варијабли између три категорије коришћена је једнофакторска AHOBA (F). Испитана је и корелација између две континуалне или једне континуалне и једне категоријске варијабле Спирмановом корелацијом ранга (r). Јачина корелације је процењена на основу Кохенових критеријума: мала ( $\mathrm{r}=0,10-0,29)$, средња $(\mathrm{r}=0,30-0,49)$ и велика корелација $(\mathrm{r}=0,50-$ $1,00)$. Све анализе су процењиване на нивоу статистичке значајности од $\mathrm{p} \leq 0,05$. Након статистичке обраде резултати су приказани табеларно.

\section{РЕЗУ ЛТАТИ}

Укупно су испитана 52 испитаника (32 мушкараца и 20 жена), просечне старости 40,4 година. Већина испитаника била је старости од 20 до 34 година $(48,1 \%)$ (табела $1)$. 
Табела 1. Демографске карактеристике испитаника и КЕП индекс

\begin{tabular}{|c|c|c|c|}
\hline & берој испитаника(\%) & ХХСД КЕП индекс & \multirow{2}{*}{ КЕП индекс } \\
\hline \multicolumn{3}{|l|}{ Пол } & \\
\hline мушки & $32(61,5)$ & $15,72 \pm 4,678$ & \multirow{2}{*}{$\mathrm{U}=303,0 ; \mathrm{p}=0,748$} \\
\hline женски & $20(38,5)$ & $15,65 \pm 5,112$ & \\
\hline \multicolumn{3}{|l|}{ Брачно стање } & \multirow{5}{*}{$C^{2}=9,779 ; p=0,008$} \\
\hline ожењен/удата & $39(75,0)$ & $16,44 \pm 3,946$ & \\
\hline неожењен/неудата & $12(23,1)$ & $12,58 \pm 5,854$ & \\
\hline удовац/удовица & $1(1,9)$ & - & \\
\hline разведен/разведена & - & - & \\
\hline \multicolumn{3}{|l|}{ Стручна спрема } & \\
\hline основна & $1(1,9)$ & - & \multirow{5}{*}{$C^{2}=3,305 ; p=0,347$} \\
\hline средња & $38(73,1)$ & $16,11 \pm 4,925$ & \\
\hline виша & $2(3,8)$ & $10,50 \pm 7,778$ & \\
\hline висока & $10(19,2)$ & $14,70 \pm 3,773$ & \\
\hline непозната & $1(1,9)$ & - & \\
\hline \multicolumn{3}{|c|}{ Старосна категорија } & \multirow{4}{*}{$C^{2}=4,682 ; p=0,096$} \\
\hline $20-34$ & $25(48,1)$ & $29,72 \pm 3,73$ & \\
\hline $35-44$ & $9(17,3)$ & $38,56 \pm 2,70$ & \\
\hline $45-64$ & $18(34,6)$ & $56,17 \pm 5,33$ & \\
\hline
\end{tabular}

У табели 2 приказане су опште животне навике испитаника које утичу на КЕП индекс. Доминантно је коришћење простих шећера у исхрани, међутим не постоји статистички значајна разлика у погледу КЕП индекса.

Табела 2. Опште животне навике које утичу на КЕП индекс

\begin{tabular}{|c|c|c|c|}
\hline & број испитаника $(\%)$ & 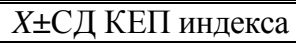 & \multirow{2}{*}{ КЕП индекс } \\
\hline \multicolumn{3}{|l|}{ Пушачки статус } & \\
\hline да & $13(25,0)$ & $16,31 \pm 5,376$ & \multirow{2}{*}{$\mathrm{U}=246,0 ; \mathrm{p}=0,873$} \\
\hline He & $39(75,0)$ & $15,49 \pm 4,650$ & \\
\hline \multicolumn{3}{|c|}{ Конзумирање алкохола } & \multirow{3}{*}{$\mathrm{U}=290,0 ; \mathrm{p}=0,377$} \\
\hline He & $26(50,0)$ & $16,19 \pm 4,508$ & \\
\hline да & $26(50,0)$ & $15,19 \pm 5,115$ & \\
\hline Сваки дан & - & & \multirow{7}{*}{$\mathrm{U}=296,0 ; \mathrm{p}=0,738$} \\
\hline Више пута недељно & $2(3,8)$ & & \\
\hline Више пута месечно & $5(9,6)$ & & \\
\hline Ретко & $19(36,5)$ & & \\
\hline \multicolumn{3}{|c|}{ Конзумирање газираних пића } & \\
\hline не & $19(36,5)$ & $15,74 \pm 4,161$ & \\
\hline да & $33(63,5)$ & $15,67 \pm 5,194$ & \\
\hline Сваки дан & $3(5,8)$ & & \multirow{8}{*}{$\mathrm{U}=74,5 ; \mathrm{p}=0,198$} \\
\hline Више пута недељно & $9(17,4)$ & & \\
\hline Више пута месечно & $5(9,6)$ & & \\
\hline Ретко & $15(28,8)$ & & \\
\hline Недостаје & $2(1,9)$ & & \\
\hline \multicolumn{3}{|c|}{ Употреба простих шећера у исхрани } & \\
\hline \multirow{2}{*}{$\begin{array}{l}\text { не } \\
\text { да }\end{array}$} & $5(9,6)$ & $17,60 \pm 3,209$ & \\
\hline & $47(90,4)$ & $15,48 \pm 4,974$ & \\
\hline Сваки дан & $11(21,2)$ & & \multirow{8}{*}{$\mathrm{U}=14,5 ; \mathrm{p}=0,096$} \\
\hline Више пута недељно & $14(26,9)$ & & \\
\hline Више пута месечно & $13(25,0)$ & & \\
\hline Ретко & $7(13,5)$ & & \\
\hline Недостаје & $2(3,8)$ & & \\
\hline \multicolumn{3}{|c|}{ На који начин се претежно храните? } & \\
\hline код куће & $48(92,3)$ & $16,06 \pm 4,710$ & \\
\hline брза храна & $4(7,7)$ & $10,50 \pm 3,536$ & \\
\hline \multicolumn{3}{|c|}{ Колико често ужинате? } & \multirow{3}{*}{$\mathrm{U}=235,0 ; \mathrm{p}=0,794$} \\
\hline више од 1 дневно & $13(25,0)$ & $15,31 \pm 5,851$ & \\
\hline повремено & $39(75,0)$ & $15,74 \pm 4,506$ & \\
\hline
\end{tabular}


Табела 3 приказује локалне факторе ризика који утичу на КЕП индекс зуба. Од укупног броја испитаника $38(73,1 \%)$ не користи конац за зубе, и код њих је статистички значајно већи КЕП индекс $(\mathrm{U}=130 ; \mathrm{p}=0,05)$. Такође, већина испитаника не користи течности за испирање уста, као ни интерденталне четкице.

Табела 3. Локални фактори ризика који утичу на КЕП индекс

\begin{tabular}{|c|c|c|c|}
\hline & број испитаника(\%) & $X \pm$ СД КЕП индекса & \multirow{2}{*}{ КЕП индекс } \\
\hline \multicolumn{3}{|c|}{ Колико често перете зубе? } & \\
\hline више пута у току дана & $32(61,5)$ & $15,63 \pm 5,278$ & \multirow{4}{*}{$C^{2}=0,287 ; p=0,866$} \\
\hline једном дневно & $19(36,5)$ & $15,89 \pm 4,135$ & \\
\hline сваки други дан & - & - & \\
\hline ретко & $1(1,9)$ & - & \\
\hline \multicolumn{3}{|c|}{ Колико временски перете зубе? } & \\
\hline краће од 1 минут & $7(13,5)$ & $16,57 \pm 3,101$ & \multirow{2}{*}{$\mathrm{U}=129,5 ; \mathrm{p}=0,451$} \\
\hline дуже од 1 минут & $45(86,5)$ & $15,56 \pm 5,025$ & \\
\hline \multicolumn{3}{|c|}{ Да ли користите конац за зубе? } & \\
\hline да & $14(26,9)$ & $12,71 \pm 3,625$ & \multirow{2}{*}{$\mathrm{U}=130 ; \mathrm{p}=0,005$} \\
\hline не & $38(73,1)$ & $16,79 \pm 4,749$ & \\
\hline \multicolumn{3}{|c|}{ Да ли користите течности за испирање уста? } & \multirow{3}{*}{$\mathrm{U}=188,5 ; \mathrm{p}=0,261$} \\
\hline да & $12(23,1)$ & $14,42 \pm 5,712$ & \\
\hline не & $40(76,9)$ & $16,07 \pm 4,503$ & \\
\hline \multicolumn{3}{|c|}{ Да ли користите интерденталне четкице? } & \multirow{3}{*}{$\mathrm{U}=122,0 ; \mathrm{p}=0,339$} \\
\hline да & $7(13,5)$ & $16,86 \pm 2,478$ & \\
\hline не & $45(86,5)$ & $15,51 \pm 5,062$ & \\
\hline \multicolumn{3}{|c|}{ Колико пута годишње мењате четкицу за зубе? } & \multirow{7}{*}{$C^{2}=2,552 ; p=0,635$} \\
\hline 1 & $1(1,9)$ & - & \\
\hline 2 & $8(15,4)$ & $15,88 \pm 3,044$ & \\
\hline 3 & $5(9,6)$ & $18,00 \pm 4,528$ & \\
\hline 4 & $17(32,7)$ & $16,12 \pm 4,167$ & \\
\hline $5-6$ & $17(32,7)$ & $14,65 \pm 6,451$ & \\
\hline непознато & $4(7,7)$ & $15,00 \pm 3,367$ & \\
\hline
\end{tabular}

Иако су сви испитаници свесни да болести уста и зуба утичу на опште здравље, највећи број испитаника, $(82,7 \%)$, има неправилну технику прања зуба и посећује стоматолога једино када осети бол. Иако су сви испитаници свесни да болести уста и зуба утичу на опште здравље, већина посећује стоматолога једино када осети бол (табела 4).

Табела 4. Показатељи квалитета оралног здравља

\begin{tabular}{|c|c|c|c|}
\hline & број испитаника(\%) & ХЕСД КЕП индекса & \multirow{2}{*}{ КЕП индекс } \\
\hline \multicolumn{3}{|c|}{ Да ли Вам десни крваре у току прања зуба? } & \\
\hline да & $24(46,2)$ & $15,67 \pm 4,631$ & \multirow{3}{*}{$\mathrm{U}=301,0 ; \mathrm{p}=0,663$} \\
\hline не & $27(51,9)$ & $15,67 \pm 5,114$ & \\
\hline непознато & $1(1,9)$ & - & \\
\hline \multicolumn{3}{|c|}{ Да ли осећате бол зуба на топло/хладно и слатко? } & \\
\hline да & $20(38,5)$ & $16,20 \pm 4,905$ & \multirow{3}{*}{$\mathrm{U}=280,5 ; \mathrm{p}=0,698$} \\
\hline не & $30(57,7)$ & $15,33 \pm 4,905$ & \\
\hline непознато & $2(3,8)$ & - & \\
\hline \multicolumn{3}{|c|}{ Колико често посећујете стоматолога? } & \\
\hline само кад осетим бол & $27(51,9)$ & $14,78 \pm 5,102$ & \multirow{2}{*}{$\mathrm{U}=272,5 ; \mathrm{p}=0,329$} \\
\hline периодични прегледи & $25(48,1)$ & $16,54 \pm 4,374$ & \\
\hline \multicolumn{3}{|c|}{ Техника прања зуба (процена стоматолога). } & \\
\hline правилна & $9(17,3)$ & $15,22 \pm 3,962$ & \multirow{2}{*}{$\mathrm{U}=168,5 ; \mathrm{p}=0,543$} \\
\hline неправилна & $43(82,7)$ & $15,79 \pm 4,993$ & \\
\hline \multirow{2}{*}{\multicolumn{3}{|c|}{$\begin{array}{l}\text { Да ли сте сагласни да болести уста и зуба утичу на опште здравље? } \\
\text { да }\end{array}$}} & \\
\hline & & & \\
\hline не & - & - & \\
\hline
\end{tabular}


У табели 5 приказана је расподела просечних вредности КЕП индекса, као и његових компоненти- каријес, екстракција зуба и пломби зуба, према старосним категоријама. Не постоји статистички значајна разлика између старосних категорија у КЕП индексу. Међутим, ако погледамо компоненте КЕП индекса, постоји статистички значајна разлика у елементу екстракције зуба $(\mathrm{F}=9,70 ; \mathrm{p}=0,000)$, при чему је просечна вредност екстракције зуба највећа у старосној категорији од 35 до 44 године $(6,56 \pm 3,88)$.

Табела 5. КЕП индекс према старосним групама

\begin{tabular}{|c|c|c|c|}
\hline КЕП индеКс & & & "КЕП индекс \\
\hline $20-34$ & $14,40 \pm 5,83$ & \multirow{3}{*}{$15,69 \pm 4,80$} & \multirow{3}{*}{$\mathrm{F}=1,945 ; \mathrm{p}=0,154$} \\
\hline $35-44$ & $16,22 \pm 2,68$ & & \\
\hline $45-64$ & $17,22 \pm 3,56$ & & \\
\hline Каријес & \multicolumn{2}{|c|}{$X \pm \mathrm{CД}$} & Каријес \\
\hline $20-34$ & $7,84 \pm 3,99$ & \multirow{3}{*}{$7,08 \pm 3,94$} & \multirow{3}{*}{$\mathrm{F}=1,151 ; \mathrm{p}=0,325$} \\
\hline $35-44$ & $7,11 \pm 3,14$ & & \\
\hline $45-64$ & $6,00 \pm 4,16$ & & \\
\hline Екстракције & \multicolumn{2}{|c|}{$X \pm \mathrm{CД}$} & Екстракције \\
\hline $20-34$ & $2,36 \pm 2,70$ & \multirow{3}{*}{$4,37 \pm 3,67$} & \multirow{3}{*}{$F=9,700 ; p=0,000$} \\
\hline $35-44$ & $6,56 \pm 3,88$ & & \\
\hline $45-64$ & $6,06 \pm 3,42$ & & \\
\hline Пломбе & \multicolumn{2}{|c|}{$X \pm \mathrm{CД}$} & Пломбе \\
\hline $20-34$ & $4,20 \pm 3,40$ & \multirow{3}{*}{$4,25 \pm 3,37$} & \multirow{3}{*}{$\mathrm{F}=1,866 ; p=0,166$} \\
\hline $35-44$ & $2,56 \pm 1,88$ & & \\
\hline $45-64$ & $5,17 \pm 3,70$ & & \\
\hline
\end{tabular}

Нађена је корелација између КЕП индекса и следећих варијабли: позитивна средња корелација са старошћу пацијената ( $\mathrm{r}=0,359$; $\mathrm{p}=0,009)$, средња корелација са брачним статусом ( $\mathrm{r}=0,297 ; \mathrm{p}=0,032)$, слаба корелација са употребом алкохола $(\mathrm{r}=0,124 ; \mathrm{p}=0,383)$, слаба корелација са употребом шећера у исхрани (r=0,182; $\mathrm{p}=0,201)$, слаба корелација са претежним начином исхране $(\mathrm{r}=0,238 ; \mathrm{p}=0,096)$, слаба корелација са учесталошћу прања зуба $(\mathrm{r}=0,106 ; \mathrm{p}=0,456)$, средња корелација са употребом конца за зубе $(\mathrm{r}=0,395 ; \mathrm{p}=0,004)$, слаба корелација са коришћењем водице за испирање уста ( $\mathrm{r}=0,157 ; \mathrm{p}=0,265)$, слаба корелација ca коришћењем интерденталних четкица $(\mathrm{r}=0,134 ; \mathrm{p}=0,344)$, слаба корелација са учесталошћу мењања четкице за зубе $(\mathrm{r}=0,170$; $\mathrm{p}=0,248)$ и слаба корелација са учесталошћу посете стоматологу ( $\mathrm{r}=0,138 ; \mathrm{p}=0,334)$.

\section{ДИСКУСИЈА}

Недостатак зуба и присуство каријесних зуба су добар показатељ оралног здравља популације ${ }^{15}$.

Према наводима АДА (American Dental Association) коришћење конца за зубе, поред четкице и пасте за зубе, представља основни вид у одржавању оралне хигијене ${ }^{16}$. У нашој студији већина испитиване популације $(73,1 \%)$ не користи конац за зубе и има не- правилну технику прања зуба, иако су годинама уназад постављани едукативни плакати о правилној техници прања зуба и коришћења конца за зубе, као и других средстава за одржавање хигијене усне дупље и континуирано вршена активна едукација о одржавању оралне хигијене војних осигураника.

Студија је показала дирекну везу између висине КЕП индекса и избегавања коришћења конца за зубе. Поред високо развијене свести, у наших испитаника, да орално здравље утиче на опште здравствено стање популациje, половина њих посећује стоматолога само када осети бол, што је знатно мање у односу на податке (68\%) које износе Madlena и сар. ${ }^{17}$. Насупрот резултатима нашег истраживања, студије у неким развијеним земљама Европе (Велика Британија, Холандија, Шведска) показују знатно виши ниво одговорности испитаника за своје орално здавље (60-95\% испитаника редовно посећује стоматолога) (18-20).

Средња вредност КЕП индекса код популације војних осигараника старости од 20-64 година износила је 15,69, што преставља високу вредност. Истраживање спроведено у Мађарској на националном нивоу, које је обухватило исте старосне групе као и наша студија, говори у прилог сличним резултатима укупног КЕП индекса (средња вредност КЕП индекса је 14,57) ${ }^{15}$. Међутим, ако посматрамо изоловано компоненте КЕП индекса, и 
поредимо их са резултатима испитивања Madlena и cap. примећујемо да су код нас око два пута више вредности каријеса зуба, близу $50 \%$ веће вредности недостајућих зуба, али присуство пломбираних зуба је за један и по пута мање у нашој студији него код Мађарске популације, у све три старосне категорије ${ }^{15}$.

Истраживања која су рађења у земљема у окружењу показују сличне резултате што се тиче средње вредности укупног КЕП индекса. Средња вредност КЕП индекса у послератном периоду у Босни и Херцеговини износила је $15,1^{21}$, док је средња вредност КЕП индек$\mathrm{ca}^{21,23}$, у централној Далмацији била знатно вeћa ${ }^{1}$.

Разлика у КЕП индексу између наше студије и испитивања Gokalp и cap. је значајно велика $^{22}$. Средња вредност КЕП индекса у Турској популацији за старосну категорију од 34 до 44 година била је 10,8. Такође, присутне су разлике и у компонентама КЕП индекса (мањи број каријесних зуба- 2,9, већи број извађених зуба- 7,4, као и мањи број пломбираних зуба- 0,9$)^{22}$.

Сличне вредности укупног КЕП индекса налазимо и у студијама неких Европских земаља. У Данској је средња вредност 16,7, међутим разлике у компонентама индекса говоре у прилог санираног оралног здравља популације (K=0,5; $\mathrm{E}=3,4 ; \Pi=12,3)$ старосне доби од 34 до 44 година ${ }^{23}$. Такође, сличне вредности компоненти КЕП индекса забележене су и у Немачкој $(K=0,5 ; E=2,4 ; \Pi=11,7)^{24}$.

Ако поредимо вредности компоненти КЕП индекса, по старосним категоријама, у нашој студији са резултатима турских ауто$\mathrm{pa}^{15}$, можемо да приметимо да у старосним групама 20-34 и 35-44 година скоро два пута већа вредност каријесне компоненте КЕП индекса код нас, али је мања вредност екстрахованих зуба, док је број пломбираних зуба исти. У испитаника старосне доби од 45 до 64 година регистрован је дупло већи број пломбираних зуба у нашој популацији.

Другим речима, компоненте КЕП индекса код наших испитаника у односу на сличне студије других аутора показују знатно већи број регистрованих каријесних и пломбираних зуба, али мањи број екстрахованих зуба, што говори у прилог чињеници да мерама санације каријеса, превентивним мерама, обуком у одржавању оралне хигијене и честим контролним прегледима можемо подићи ниво оралног здравља у нашој популацији.
Наставак студије и нова истаживања треба да потврде или оповргну ове претпоставке везане за орално здравље зуба посматрано КЕП индексом. Овакви видови епидемиолошких истраживања могу дати потребне информације о преваленцији каријеса у одређеним старосним групама, указати на могућности санације каријеса и смањења учесталости каријеса подстицањем превентивних мера кроз већу активност стоматолошке службе на плану едукације становништва. Сама свест становништва о значају оралне хигијене није довољна, јер код наших испитаника није довела до смањења КЕП индекса.

\section{ЗАХВАЛНИЦА}

Аутор се захваљује Министарству просвете Републике Србије за финансирање пројекта бр. 175014.

\section{ЛИТЕРАТУРА}

1. Bego K, Njemirovskij V, Pelivan I. Epidemiological research on oral health in central Dalmatia: A pilot study. Acta Stomatol Croat 2007; 41(4): 337-44.

2. Paulander J, Axelsson P, Lindhe J. Association between level of education and oral health status in 35, 50-, 65- and 75-year olds. J Clin Periodontol 2003; 30(8): 697-704.

3. Cruz GD, Shore R, le Geros RZ, Tavares M. Effect of acculturation on objective measures of oral health in Haitian immigrants in New York City. J Dent Res 2004; 83(2):180-4.

4. Stojanović N, Krunić J. Prevalenca karijesa u studenata u medicine i stomatologije u Opštini Foča. Stomatološki glasnik Srbije 2007; 54(2): 89-96.

5. Bowen WH. Nature of plaque. Oral Sci Rev 1976; 9: 3-21.

6. Tinanoff N. Dental caries risk assessment and prevention. Dent Clin North Am 1995; 39(4): 709-19.

7. Lang NP, Cumming BR, Löe H. Toothbrushing frequency as it relates to plaque development and gingival health. J Periodontol 1973; 44(7): 396-405.

8. Bowden GH. Controlled environment model for accumulation of biofilms of oral bacteria. Methods Enzymol 1999; 310: 216-24.

9. Axelsson P, Lindhe J. Efficacy of mouth rinses in inhibiting dental plaque and gingivitis in man. J Clin Periodontol 1987; 14: 205-12.

10. Lang WP, Ronis DL, Farghaly MM. Preventive behaviors as correlates of periodontal health status. J Public Health Dent 1995; 55(1): 10-7.

11. Touger-Decer R, Mobley CC, American Dietetic Association. Position of the American Dietetic Association: Oral health and nutrition. J Am Diet Assoc 2003; 103(5): 615-25.

12. Touger-Decer R, van Loveren C. Sugars and dental caries. Am J Clin Nutr 2003; 78(4): 881-92. 
13. World Health Organization. Oral Health Surveys. Basic Methods. 4th ed. Geneva: World Health Organization; 1997.

14. Papas A, Joshi A, Giunta J. Prevalence and intraoral distribution of coronal and root caries in middle-aged and older adults. Caries Res 1992; 26(6): 459-65.

15. Madléna M, Hermann P, Jáhn M, Fejérdy P. Caries prevalence and tooth loss in Hungarian adult population: results of a national survey. BMC Public Health $2008 ; 8: 364$.

16. American Dental Association. Brushing your teeth (Cleaning Your Teeth \& Gums). (Посећено у мају 2012. на http://www.ada.org/5624.aspx?currentTab=1).

17. Madléna M, Hermann P, Tollas O, Gerle J, Fejérdy P. Oral hygienic, nutritional habits and dental surgeon attendance of Hungarian adult population. Fogorv Sz 2007; 100(3): 91-7.

18. Kalsbeek H, Poorterman JHG, Verrips GH, Eikmann MJ. Changes in Caries Prevalence in Dutch Juveniles. Caries Res 2000; 34: 312.

19. Hugoson A, Koch G, Bergendal T, et al. Oral health of individuals aged 3-80 years in Jonkoping Sweden in
1973, 1983 and 1993. I. Review of findings on dental care and oral care habits and knowledge of oral health. Swed Dent J 1995; 19: 225-41.

20. Kelly M, Nuttall N, Bradnock G, et al. Adult dental health Survey: Oral Health in the United Kingdom 1998. London: The Stationery Office; 2000.

21. Ivanković A, Lukić IK, Ivanković Z, Radić A, Vukić I, Simić A. Dental caries in postwar Bosnia and Herzegovina. Community Dent Oral Epidemiol 2003; 31(2): 100-4.

22. Gökalp SG, Doğan BG, Tekçiçek MT, Berberoğlu A, Unlüer S. National survey of oral health status of children and adults in Turkey. Community Dent Health 2010; 27(1): 12-7.

23. Oral Health Database. Dental Caries. (Посећено у мају 2012. на http://www.mah.se/CAPP/Country-OralHealth-Profiles/EURO/Denmark/OralDiseases/Dental-Caries/).

24. Oral Health Database. Dental Caries. (Посећено у мају 2012. на http://www.mah.se/CAPP/Country-OralHealth-Profiles/EURO/Germany/OralDiseases/Dental-Caries/). 